Brit. J. industr. Med., 1964, 21, 94.

\title{
LUNG CANCER IN A FLUORSPAR MINING COMMUNITY I. Radiation, Dust, and Mortality Experience
}

BY

\author{
A. J. de VILLIERS and J. P. WINDISH \\ From the Occupational Health Division, Department of National Health and Welfare, Ottawa, Canada
}

(RECEIVED FOR PUBLICATION MAY 22, 1963)

\begin{abstract}
Since 1952 two to three deaths from primary cancer of the lung have occurred regularly each year among the male inhabitants of the small fluorspar mining community of St. Lawrence, Newfoundland. These constituted 23 of the 51 deaths that occurred during the 10-year period 1952-61 among employees with one or more years of underground mining experience. A shift to a younger average age at death from lung cancer and an association between age at entry into risk and age at death were observed. Comparisons between the mortality experience of the inhabitants of St. Lawrence, of a control community of comparable size in the same geographical region, and of the population of the rest of Newfoundland confirmed the probability of an occupational factor, the observed death rate from lung cancer being about 29 times the expected.

The outstanding environmental finding in the fluorspar mines was the discovery of concentrations of radon and daughter products in the air well in excess of suggested maximum permissible concentrations. On the basis of these concentrations and other considerations, it is suggested that underground workers were probably exposed to an average potential alpha-energy to complete decay of between 2.5 and 10 times the previously suggested working level of $1.3 \times 10^{5} \mathrm{Mev}$ per litre of air (Holaday, Rushing, Coleman, Woolrich, Kusnetz, and Bale, 1957). That these levels were obtained in mines in which no radioactive ore bodies have been found is of exceptional interest.

The findings at St. Lawrence are compared with those reported in the literature for uranium mines.
\end{abstract}

For some years the Newfoundland Department of

Health has been concerned about the incidence of pulmonary disease among the fluorspar miners of St. Lawrence.

Tuberculosis has long been a major public health problem in Newfoundland (Garland and Hart, 1946), and a certain incidence of this disease in a mining population was to be expected. A number of cases of pneumoconiosis had also been recognized during the previous 10 to 12 years. However, interest centred on an apparently high incidence of lung cancer which seemed to affect only the male population of St. Lawrence.

In 1956, at the request of the Newfoundland Department of Health, the Occupational Health Division of the Department of National Health and Welfare began studying the extent of dust hazard in the mines. In 1958 the scope of this project was expanded to include radiation measurements, epidemiological and clinical investigations, and experimental laboratory studies. Community as well as occupational factors were included.

\section{St. Lawrence}

St. Lawrence is located on the south-east tip of the Burin Peninsula, which is the southern portion of the long boot-shaped peninsula on the south coast (Fig. 1). At the 1956 census the population of St. Lawrence was 2,078 .

Temperatures in this area rarely fall below $0^{\circ} \mathrm{F}$. $\left(-17.8^{\circ} \mathrm{C}\right.$.) in the winter or rise above $80^{\circ} \mathrm{F}$. $\left(26.7^{\circ} \mathrm{C}\right.$.) in the summer. Annual precipitation is approximately $50 \mathrm{in}$. $(127 \mathrm{~cm}$.). The area is frequently blanketed by fog or swept by high winds.

The terrain is characterized by rocky outcrops, low-lying hills, and sparse and stunted vegetation; $90 \%$ of the St. Lawrence area is treeless. The soil is thin, and few areas are suitable for agricultural purposes. A great variety of minerals occurs in the area, but fluorspar is the only one known to be present in economic quantities.

For many years St. Lawrence was an isolated fishing community located along the natural harbours of Great and Little St. Lawrence. Practically 


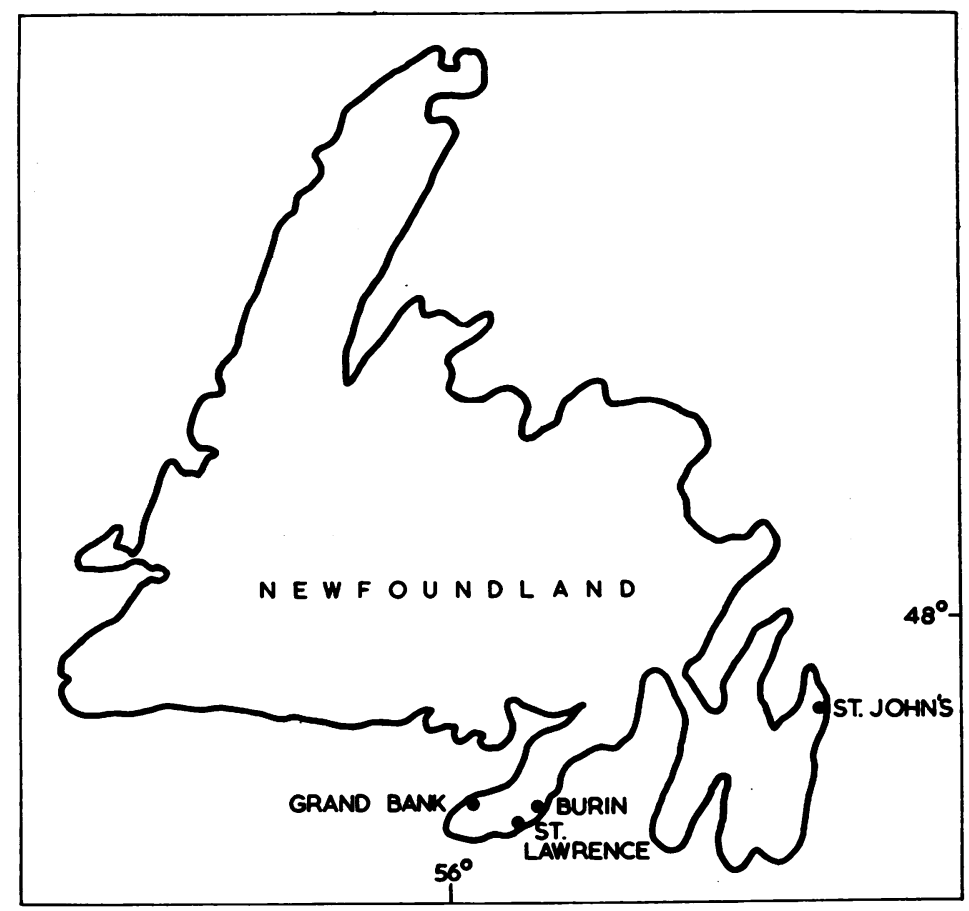

FIGURE 1

the only means of communication with other parts of the island was by sea. Little migration of population took place. The sale of salt-cured fish was the chief source of income. Shortly after World War I the price of salt-cured fish started to drop. The gradual economic decline that followed in St. Lawrence reached a disastrous level with the simultaneous occurrence of the depression years and the Grand Banks earthquake and accompanying tidal wave of 1929. The tidal wave destroyed all the fishing equipment in St. Lawrence; the earthquake disrupted the fishing grounds. By 1933 the inhabitants of the area were poverty-stricken, and malnutrition was prevalent (Adamson, Jollife, Kruse, Lowry, Moore, Platt, Sebrell, Tice, Tisdall, Wilder, and Zemechnik, 1945).

Just at this time economic development of the fluorspar deposits began. This provided work for a number of men in the community, and eventually mining displaced fishing as their principal occupation.

\section{Mining Development}

Fluorspar (fluorite, calcium fluoride, $\mathrm{CaF}_{2}$ ) is used in the making of aluminium and steel and as a source of fluorine in the manufacture of such chemicals as hydrogen fluoride and various fluorinated hydrocarbons.
The St. Lawrence fluorspar occurs as epithermal veins filling fault-fissures, chiefly in granite. These veins generally dip between $70^{\circ}$ and $90^{\circ}$ and are from less than 1 in. $(25.4 \mathrm{~mm}$.) to more than $50 \mathrm{ft}$. $(15.24 \mathrm{~m}$.) wide. The higher-grade veins are usually narrow, having an average width of 4 to $5 \mathrm{ft}$. $(1 \cdot 2-1.5 \mathrm{~m}$.), an average fluorite content of $90 \%$, and an average silica content of $5 \%$ to $6 \%$; random samples have contained 0.02 to $0.4 \%$ manganese, 0.002 to $0.01 \%$ nickel, $<0.01 \%$ chromium, and $0.27 \%$ yttrium; neither arsenic nor cerium has been detected (analyses by Mines Branch, Ottawa). The only rare earth so far reported is the naturally radioactive samarium-147, which was present in one sample to the extent of not more than $0.05 \times 10^{-12}$ curie/g. (value obtained through the courtesy of Professor W. V. Mayneord, London).

The lower-grade veins have an average width of 15 to $20 \mathrm{ft}$. (4-5-6.0 m.), an average fluorite content of 60 to $70 \%$, and an average silica content of 15 to $20 \%$. In the wider, lower-grade veins, the silica occurs both as free silica in the granite and as finely disseminated silica mixed with fluorite (locally termed 'blastonite'). The calcite content is generally low but may become appreciable in certain locations (the average is about $10 \%$ ). Although about 40 veins have been located in the St. Lawrence area, most of the ore produced has come from only three 
TABLB 1

MAIN CHARACTERISTICS UP TO DECEMBER 1959 OF FIVE ST. LAWRENCE MINES

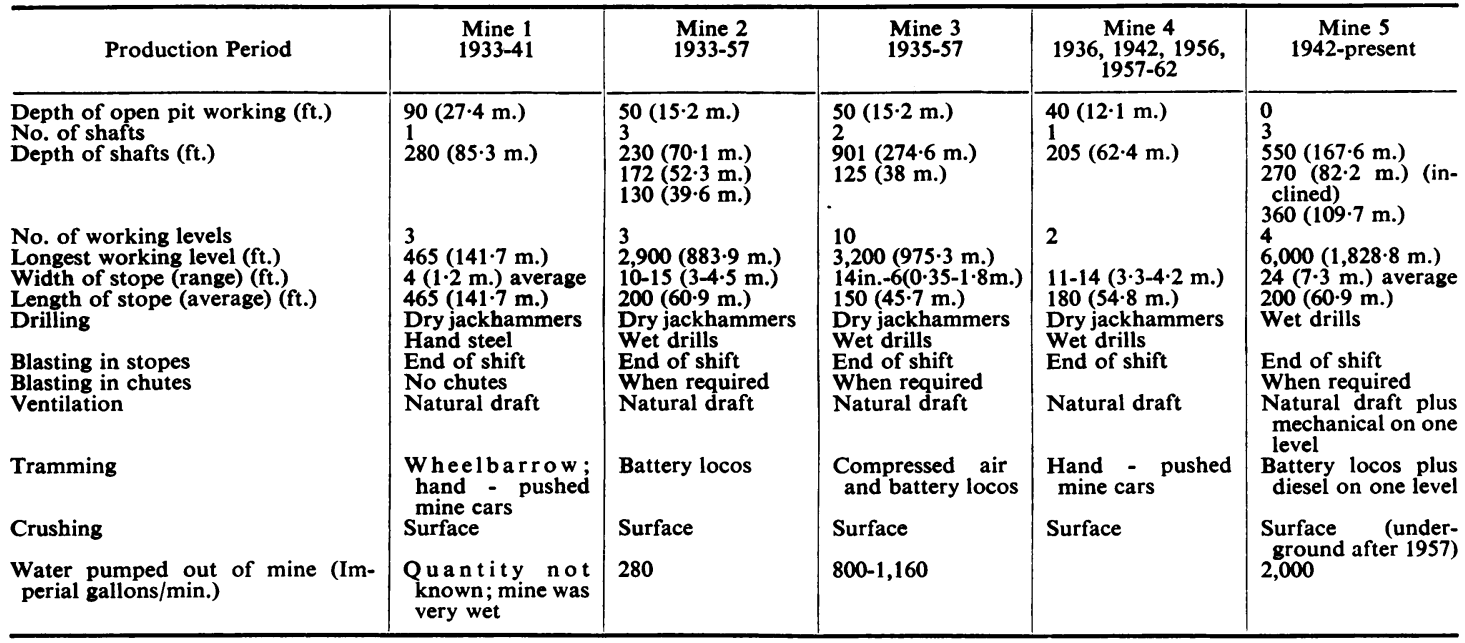

major ones (Van Alstine, 1948; Snelgrove and Baird, 1953; Carr, 1958; Newfoundland Fluorspar Ltd., personal communication, 1962).

The modern phase of mining development began in 1933. A summary of the main characteristics of five of the mines is given in Table 1.

Initially, development was by open cut, using quite primitive tools. Later, shafts were sunk and the ore was extracted by standard underground mining procedures. However, it was not until 1942 that wet drilling came into general use. Shrinkage stoping methods were used until very recently when cut-and-fill methods were adopted. Ore was usually extracted from the stopes in approximately $6-\mathrm{ft}$. $(1.8 \mathrm{~m}$.) lifts, this process being continued until the stope reached the level above. In mine No. 3, connecting raises between levels were driven at the ends of the stopes after the stope had reached a height of 45 to $60 \mathrm{ft}$. $(13 \cdot 7-18 \cdot 2 \mathrm{~m}$.) above the drift level (Carr, 1958). In mine No. 5, such raises were driven before stope extraction began. Chutes were small, and the flow of muck in them was frequently blocked by large pieces of ore that required on-shift blasting. All the mines were extremely wet, so that the men had to wear rubberized clothing. Underground air temperatures were approximately $45^{\circ} \mathrm{F} .\left(7 \cdot 2^{\circ} \mathrm{C}\right.$.).

Ventilation was by natural draft, occasionally assisted by small supplementary blowers. One major exception to this was on the second level of mine No. 5 where a diesel locomotive has been in use for haulage since 1952. Approximately $10,000 \mathrm{cu}$. $\mathrm{ft}$./min. of air was supplied to this level by mechanical means.
The spar was separated from the waste rock mainly by sink-and-float methods, using a ferrosilicon suspension. Froth flotation was used to a limited extent.

\section{Environmental Studies}

Airborne Dust and Fluoride Measurements.-During 1956 and 1957, samples of airborne dust were collected on membrane filters in five St. Lawrence mines and analysed for quartz and calcium fluoride content by means of $x$-ray diffraction. The results are summarized in Table 2.

TABLE 2

QUARTZ AND CALCIUM FLUORIDE CONTENT OF AIRBORNE DUSTS IN FIVE ST. LAWRENCE MINES (1956-57)

\begin{tabular}{l|c|c}
\hline & $\begin{array}{c}\text { Underground } \\
\text { Operations }\end{array}$ & $\begin{array}{c}\text { Surface } \\
\text { Operations }\end{array}$ \\
\cline { 2 - 3 } No. of working places sampled & 9 & 8 \\
Quartz in airborne dust (\%): & & \\
Range \\
Mean \\
$\begin{array}{c}\text { Median } \\
\mathrm{CaF}_{2} \text { in airborne dust (\%): }\end{array}$ & $4-38$ & $6-44$ \\
Range & 19 & 26 \\
Mean \\
Median & 20 & 25 \\
& $26-96$ & $40-86$ \\
& 62 & 62 \\
& 64 & 59 \\
\hline
\end{tabular}

In six mines, airborne dust concentrations were determined by the midget impinger and standard lightfield counting technique; airborne fluoride concentrations were determined by collecting samples in sodium hydroxide solution and analysing them by a modified Willard and Winter technique. A total of 180 individual airborne dust concentration measurements were made at 
TABLE 3

AIRBORNE DUST AND FLUORIDE CONCENTRATIONS IN SIX ST. LAWRENCE MINES (1956-57)

\begin{tabular}{|c|c|c|c|c|c|c|c|c|c|c|}
\hline \multirow{4}{*}{ Operation } & \multicolumn{5}{|c|}{ Airborne Dust } & \multicolumn{5}{|c|}{ Airborne Fluoride } \\
\hline & \multicolumn{2}{|c|}{ No. of Places } & \multirow{2}{*}{\multicolumn{3}{|c|}{ Concentration (m.p.p.c.f.) }} & \multicolumn{2}{|c|}{ No. of Places } & \multirow{2}{*}{\multicolumn{3}{|c|}{$\begin{array}{l}\text { Concentration } \\
\text { (mg. F per } \mathrm{m}^{3} \text {.) }\end{array}$}} \\
\hline & \multirow{2}{*}{ Sampled } & \multirow{2}{*}{$\begin{array}{l}\text { Where Conc. } \\
\text { above t.l.v.* }\end{array}$} & & & & \multirow{2}{*}{ Sampled } & \multirow{2}{*}{$\begin{array}{l}\text { Where Conc. } \\
\text { above t.l.v.** }\end{array}$} & & & \\
\hline & & & Range & Mean & Median & & & Range & Mean & Median \\
\hline \multirow{3}{*}{$\begin{array}{l}\text { Preparing to work, scaling, } \\
\text { loading holes } \\
\text { Drilling } \\
\text { Raising } \\
\text { Mucking and slushing } \\
\text { (scraping) } \\
\text { Pulling chutes } \\
\text { After blasting chutes } \\
\text { Crushing and screening } \\
\text { (on surface) } \\
\text { Sample preparation rooms }\end{array}$} & $\begin{array}{r}9 \\
21 \\
1\end{array}$ & $\begin{array}{l}0 \\
5 \\
1\end{array}$ & $\begin{array}{c}0 \cdot 0-19 \cdot 0 \\
1 \cdot 1-43 \cdot 0 \\
85 \cdot 0\end{array}$ & $\begin{array}{r}5 \cdot 3 \\
15 \cdot 5\end{array}$ & $\begin{array}{r}3 \cdot 2 \\
11 \cdot 0\end{array}$ & $\begin{array}{r}1 \\
17 \\
0\end{array}$ & $\begin{array}{l}0 \\
0\end{array}$ & $\begin{array}{c}0 \cdot 11 \\
0 \cdot 00-1 \cdot 72\end{array}$ & 0.49 & $0 \cdot 34$ \\
\hline & $\begin{array}{r}12 \\
7 \\
2\end{array}$ & $\begin{array}{l}1 \\
\mathbf{0} \\
\mathbf{0}\end{array}$ & $\begin{array}{l}0 \cdot 5-51 \cdot 0 \\
0 \cdot 0-11 \cdot 3 \\
5 \cdot 2-10 \cdot 0\end{array}$ & $\begin{array}{l}8 \cdot 9 \\
4 \cdot 4\end{array}$ & $\begin{array}{l}5 \cdot 3 \\
3 \cdot 1\end{array}$ & $\begin{array}{l}3 \\
4 \\
2\end{array}$ & $\begin{array}{l}\mathbf{0} \\
\mathbf{0} \\
\mathbf{0}\end{array}$ & $\begin{array}{c}0.012-0.70 \\
0.61-0.97 \\
0.01-0.01\end{array}$ & $\begin{array}{l}0 \cdot 27 \\
0 \cdot 77\end{array}$ & $\begin{array}{l}0.09 \\
0.75\end{array}$ \\
\hline & $\begin{array}{l}6 \\
2\end{array}$ & $\begin{array}{l}\mathbf{0} \\
\mathbf{2}\end{array}$ & $\begin{array}{c}6 \cdot 7-15 \cdot 0 \\
21-271\end{array}$ & 10.9 & $11 \cdot 0$ & $\begin{array}{l}5 \\
2\end{array}$ & $\begin{array}{l}\mathbf{0} \\
\mathbf{0}\end{array}$ & $\begin{array}{l}0.002-0.52 \\
0.18-0.32\end{array}$ & $0 \cdot 13$ & 0.05 \\
\hline
\end{tabular}

*t.l.v. (threshold limit value) for dust $=20$ m.p.p.c.f. (millions of particles per cubic foot of air).

$* *$ t.l.v. for fluoride $=2 \cdot 5 \mathrm{mg}$. F per $\mathrm{m}^{3}$.

60 different locations representing 15 different operations; at nine of these locations, representing four different operations, the average concentration was above the American Conference of Government and Industrial Hygienists threshold limit value. A total of 67 individual measurements of airborne fluoride concentrations were made at 34 different locations, representing 11 different operations. Concentrations above the threshold limit value were not found on any occasion. A summary of these data is given in Table 3. Excluded from the table are data for two infrequent short-time operations, where dust concentrations as high as 710 and 24,000 million particles per cubic foot of air were found.

Radioactivity.- - Radon daughter concentrations in the air of the working places in two underground mines (Nos. 4 and 5, Table 1) and of the two surface plants were measured in November 1959. Radon concentrations in the same two mines were measured during a second visit to the area in December 1959, but because of a damaged instrument, simultaneous measurements of radon daughter concentrations could not be made. Some measurements of gamma fields were also obtained.

At the time that these measurements were being made, a large part of the available ore in mine No. 5 had been blocked off by a major fall of ground, so that operations during this period could not be regarded as normal.

Measuring Techniques.-The method used for the determination of radon daughter concentrations was that described by Kusnetz (1956) and by Holaday et al. (1957). This included drawing 30 to 50 litres of air (at a rate of 8 to 10 litres/min.) through a 1 in. $(25.4 \mathrm{~mm}$.) diameter membrane filter*; measuring the alpha activity on the filter, some time between 40 and 90 minutes after the end of sampling, by means of a portable (6 lb. $(2 \cdot 72 \mathrm{~kg}$.)) transistorized, battery-operated scintillation detector

*Type AA made by Millipore Filter Corporation, Bedford, Mass Reference here and elsewhere in the text of this article to specific makes of equipment is for identification purposes only of the type of equipment used and should not be construed to constitute a specia endorsement thereof by the Department of National Health and Welfare.
(Transcint)* equipped with a ratemeter having ranges of $0-1,000,0-10,000$, and $0-100,000$ counts $/ \mathrm{min}$.; then converting observed counts per minute to total alpha-energy to complete decay, per unit volume of air sampled, at the time of sampling. Kusnetz found that, even under conditions of extreme non-equilibrium, the use of his method resulted in a maximum error of from $12 \%$ overestimation to $7 \%$ underestimation of the total potential alphaenergy to complete decay. These possible errors are small compared with other uncertainties in estimating the human hazard from breathing radon and radon daughter products.

The Transcint was carried throughout the day in the mine; readings were made whenever required at the nearest convenient location. Repeated checks of the instrument revealed no contamination. The efficiency of the instrument, which was checked daily by the use of a radium foil standard source, was approximately $33 \%$.

Samples for radon-222 measurements were collected by admitting air through a membrane filter into an evacuated aluminium chamber having interior dimensions of $4 \frac{1}{2}$ in. (114 mm.) diameter and $\frac{3}{4}$ in. $(19 \mathrm{~mm}$.) depth; the interior surface of the aluminium was covered with white enamel. One side of the chamber was a lucite window (sealed with an ' $O$ ' ring) coated on the inside with zinc sulphide phosphor. The radon samples were counted above ground, after the radon daughters had reached equilibrium, by placing the lucite windows of the sample chambers over a photomultiplier tube in a light-tight box. After a few minutes in darkness had been allowed for decay of phosphorescence, the activities of the samples were measured with a ratemeter unit (or, in the case of low activity samples, with a simple scaling circuit). From these data, the concentrations of radon existing in the air at the times of sampling were calculated (Simpson, Stewart, Yourt, and Bloy, 1958).

Gamma radiation levels were measured by means of a Geiger-type instrument + , whose calibration had been

*Nuclear Enterprises Limited, Winnipeg, Canada, and Edinburgh, Scotland.

†Model 408 Alpha-Beta Gamma Monitor, Universal Atomitics, †Model 408 Alpha-Beta
Westbury, L.I., New York. 
checked in the laboratory by means of a radium source. The shielding around the tube was sufficient to absorb all beta particles except those having an energy greater than $1 \mathrm{Mev}$ (million electron volts).

The instrument was broken towards the end of the survey before measurements could be made on the bottom level of mine No. 5 where the highest radon daughter concentrations had been found. Film badges were therefore set up on stakes at two different locations on this level of the mine and collected after periods of exposure of two, four, and six weeks. Some of these films were sealed in plastic envelopes to protect them from moisture.

From May to December 1960, each worker in mine No. 5 wore a film badge, which was changed each month. No special precautions were taken to protect these films against moisture, and no corrections were made for the possible effects of humidity. All badges were supplied and evaluated by the Radiation Protection Division, Department of National Health and Welfare, Ottawa.

Identification of the Materials Sampled.-This was done by determining the half-lives of two membrane-filter samples. The rate of decay of one, measured between 130 and 350 minutes after sampling, indicated a half-life of 32 minutes; the rate of decay of the other, measured between 65 and 300 minutes after sampling, indicated a half-life of 33 minutes. These values are compatible with those observed from known mixtures of radon daughters, measured at comparable times after sampling.

The half-lives of three gaseous samples were found to be $3.4,3.6$, and 3.85 days respectively. The half-life of radon-222 is 3.825 days.

Further indirect evidence that the radioactive materials in the mine atmosphere were radon-222 and its daughters was provided when five water samples, collected at various underground locations, were analysed by gamma spectrometry at the laboratories of Atomic Energy of Canada Limited, Chalk River (A.E.C.L.); the activities of the samples decayed with a half-life of 3.8 days, while the spectrum observed in each case was that of the radon daughters.

Maximum Permissible Levels.-Although it is usually easier, in the field, to measure radon daughters rather than radon, no maximum permissible concentrations in air $\left((\mathrm{MPC})_{\mathrm{a}}\right)$ for daughters alone has been established by the International Commission on Radiological Protection (I.C.R.P.). However, Holaday et al. (1957) proposed that $1.3 \times 10^{5} \mathrm{Mev}$ of potential alpha-energy per litre for radon daughters $(\mathrm{RaA}, \mathrm{RaB}$, and $\mathrm{RaC})$ be used as a suggested working level (SWL) for a 40-hour week exposure. This is the amount of energy that will be released by the decay, through $\mathrm{RaC}^{\prime}$ of 100 pico-curies (pc) of each of these elements, and these are the quantities of the daughter products that would be in equilibrium with $100 \mathrm{pc}$ of radon.

The latest (1959) I.C.R.P. recommendations, which establish an (MPC) $)_{a}$ for radon (plus daughters 'to the extent they occur in ulfiltered air') of 30 pc per litre, were not released until after the completion of our field work. Furthermore, the SWL proposed by Holaday et al. is still being widely used to evaluate exposure hazards in uranium mines in Canada and the United States of America. We have therefore reported our data in terms of multiples, or fractions, of the SWL of $1.3 \times 10^{5} \mathrm{Mev}$ per litre for radon daughters, and of the associated SWL of $100 \mathrm{pc}$ per litre for radon.

For occupational exposure to external gamma radiation, the 1959 I.C.R.P. recommendations imply that the whole body average exposure rate should not exceed 100 milliroentgens $(\mathrm{mr})$ per 40 -hour week, which is equivalent to $2.5 \mathrm{mr}$ per hour.

Data.-Radon and radon daughter measurements are summarized in Table 4. For locations where more than

TABLE 4

FREQUENCY OF OCCURRENCE OF SPECIFIED CONCENTRATIONS OF RADON-222 AND RADON DAUGHTERS IN TWO ST. LAWRENCE MINES

\begin{tabular}{|c|c|c|c|}
\hline \multirow{3}{*}{$\begin{array}{c}\text { Concentration Ranges as } \\
\text { Fractions or Multiples } \\
\text { of SWL }\end{array}$} & \multicolumn{3}{|c|}{$\begin{array}{l}\text { No. of Locations at which Specified } \\
\text { Concentration Found }\end{array}$} \\
\hline & \multirow{2}{*}{$\begin{array}{c}\text { Radon-222 } \\
\text { Under- } \\
\text { ground }\end{array}$} & \multicolumn{2}{|c|}{ Radon Daughters } \\
\hline & & $\begin{array}{l}\text { Under- } \\
\text { ground }\end{array}$ & Surface \\
\hline $\begin{array}{c}\text { N.M.**- } 0 \cdot 30 \\
0 \cdot 31-1 \cdot 0 \\
1 \cdot 1-5 \cdot 0 \\
5 \cdot 1-10 \cdot 0 \\
10 \cdot 1-100 \\
>100 \\
\text { Total no. of locations } \\
\text { Total no. of samples }\end{array}$ & $\begin{array}{r}2 \\
2 \\
5 \\
3 \\
3 \\
2 \\
17 \\
17\end{array}$ & $\begin{array}{r}5 \\
9 \\
20 \\
9 \\
6 \\
1 \\
50 \\
80\end{array}$ & $\begin{array}{r}17 \\
1 \\
1\end{array}$ \\
\hline
\end{tabular}

*SWL for radon $=100 \mathrm{pc} /$ litre.

SWL for radon daughters $=1.3 \times 10^{5} \mathrm{Mev}$ total potential alpha-energy per litre.

$*$ N.M. $=$ not measurable.

one radon daughter sample was taken the concentration values were averaged, and this average value was used to assign this location to a concentration range.

In mine No. 4, the mean value of the average concentrations of radon daughters found in all the working places was $2.95 \times$ SWL. The range of these average concentrations was $<0.05$ to $15.7 \times$ SWL; the median was $0.77 \times$ SWL. The highest individual value was $27 \times$ SWL.

Values of individual radon samples taken at four different working places in this mine were $54,123,510$, and $1,250 \mathrm{pc}$ per litre.

In the much larger and deeper mine No. 5, the average radon daughter concentrations in nine accessible working places (which included only one stope), which were ventilated by natural draft, ranged from 0.4 to $8.0 \times$ SWL, with a mean of 3.6 and a median of 3.5 . For five other working locations, which were ventilated by mechanical means, the range was 0.3 to $1 \cdot 3$, mean 0.7 , and median $0 \cdot 6$.

In non-working, unventilated areas of mine No. 5, considerably higher radon daughter concentrations were found, the highest individual value being $193 \times$ SWL.

Values of individual radon samples taken in working areas in this mine ranged from $<0.2$ to $1,510 \mathrm{pc}$ per litre (average 490, median 297). The highest concentration actually measured in a non-working area was $13,300 \mathrm{pc}$ per litre. However, on the basis of the comparative values 
TABLE 5

RADON-222 CONCENTRATIONS IN TWO MINES COMPARED WITH RADON DAUGHTER CONCENTRATIONS AND WITH RADON DAUGHTER CONCENTRATIONS AND
GAMMA RADIATION FIELDS MEASURED AT THE SAME
LOCATIONS

\begin{tabular}{|c|c|c|c|}
\hline $\begin{array}{l}\text { Location } \\
\text { No. }\end{array}$ & Radon-222 & $\begin{array}{c}\text { Radon } \\
\text { Daughters }\end{array}$ & $\underset{(\mathrm{mr} / \mathrm{hr})}{\mathrm{Gamma}}$ \\
\hline 1 & $<0.2 \times \mathrm{SWL}^{* *}$ & $2 \cdot 1 \times \underset{1 \cdot 2}{S_{W L} * * *}$ & 0.03 \\
\hline 2 & 0.26 & N.D. & N.D. \\
\hline 3 & 0.5 & 0.5 & N.D. \\
\hline 4 & 0.8 & 0.9 & 0.07 \\
\hline 5 & $1 \cdot 2$ & 0.5 & 0.15 \\
\hline 6 & $1 \cdot 2$ & N.D. & N.D. \\
\hline 7 & $2 \cdot 6$ & $\begin{array}{l}2 \cdot 7 \\
4 \cdot 4\end{array}$ & 0.06 \\
\hline 8 & $2 \cdot 7$ & $\begin{array}{l}4 \cdot 5 \\
2 \cdot 7\end{array}$ & N.D. \\
\hline 9 & $3 \cdot 3$ & $4 \cdot 2$ & 0.04 \\
\hline 10 & $5 \cdot 1$ & $\begin{array}{l}1 \cdot 5 \\
0.6\end{array}$ & N.D. \\
\hline 11 & $6 \cdot 4$ & N.D. & 0.04 \\
\hline 12 & $6 \cdot 6$ & N.D. & 0.07 \\
\hline 13 & $12 \cdot 5$ & $\begin{array}{l}27 \\
4 \cdot 5\end{array}$ & N.D. \\
\hline 14 & $13 \cdot 1$ & N.D. & 0.07 \\
\hline 15 & $15 \cdot 1$ & $\begin{array}{c}11 \\
8.9 \\
9.8\end{array}$ & 0.08 \\
\hline 16 & 110 & 84 & $0 \cdot 35$ \\
\hline 17 & 133 & N.D. & 0.50 \\
\hline
\end{tabular}

* For maximum permissible exposure rate to gamma radiation see text.

* SWL for radon-222 $=100 \mathrm{pc} /$ litre

$* * * S W L$ for radon daughters $=1.3 \times 10^{5} \mathrm{Mev} /$ litre

N.D. = not determined.

Radon and gamma measurements were made simultaneously.

Radon daughter measurements were made two to six weeks previously.

Where more than one radon daughter concentration is shown for one location, the different values were obtained on different days.

of radon and radon daughters given in Table 5, it may be roughly estimated that the radon concentration associated with the radon daughter level of $193 \times$ SWL previously mentioned was 25,000 pc per litre.

In the two surface plants, radon daughter concentrations were low, many being below the limit of detection of the Transcint (about $0.05 \times \mathrm{SWL}$ ). The only place where the SWL was exceeded was inside a shaft bin where the ore is dumped when it comes up from the mine. Values of 0.9 and $1.6 \times$ SWL were obtained here on two separate occasions.

After completion of this work, further measurements were made in one of the mines by an independent consulting firm, who used an ionization chamber method for measuring the activity of the radon daughters. In general, their results confirmed our findings.

Gamma radiation dose rates, as measured by a Geiger instrument, are given in Table 5. All were well below the acceptable value of $2.5 \mathrm{mr} / \mathrm{hr}$. The two highest values,
0.35 and $0.50 \mathrm{mr} / \mathrm{hr}$, were obtained in an abandoned unventilated drift on the second level in which water had been dammed to a height of $3 \frac{1}{2} \mathrm{ft}$. $(1.06 \mathrm{~m}$.); $0.35 \mathrm{mr} / \mathrm{hr}$ was associated with a radon concentration of $11,000 \mathrm{pc}$ per litre at a point $100 \mathrm{ft}$. $(30.4 \mathrm{~m}$.) inside the drift (location no. 16, Table 5); $0.50 \mathrm{mr} / \mathrm{hr}$ was associated with a radon concentration of $13,300 \mathrm{pc}$ per litre $180 \mathrm{ft}$. $(54.8 \mathrm{~m}$.) inside the drift (location no. 17).

Values similar to those found at location no. 16 were obtained by film badges on stakes at one location on the bottom level of mine No. 5. The gamma dose rate here was $120 \mathrm{mr} / 2$ weeks (equivalent to $0.36 \mathrm{mr} / \mathrm{hr}$ ), while the average radon daughter concentration was $106 \times$ SWL. At another location on this same level, the gamma dose rate as measured by film badges was $25 \mathrm{mr} / 2$ weeks (equivalent to $0.074 \mathrm{mr} / \mathrm{hr}$ ).

None of the film badges worn by the miners indicated exposures in excess of $20 \mathrm{mr} / 4$ weeks. The limit of detection for radium gamma rays using the film method was about $20 \mathrm{mr}$.

\section{Medical Studies}

Medical studies have included the retrospective analysis of collected mortality data and a detailed clinical investigation of more than 380 employees and ex-employees. The mortality data are reported here.

Causes and Classification of Deaths among Fluorspar Miners.-Information about the deaths of the inhabitants of the Burin Peninsula during the period 1933-61 was obtained from death certificates filed with the Registrar-General of Newfoundland and the Dominion Bureau of Statistics, and from parish records. The deaths of permanent residents, which occurred while they were temporarily absent from this area, were also included. These data supported the suggestion that a high incidence of lung cancer had occurred among St. Lawrence men. All these men had worked for the mining companies at St. Lawrence, according to further information obtained from census data, payrolls, company insurance records, and interviews with mining company and labour union officials. From these sources and from questioning more than 380 mining and ex-mining employees during a subsequent clinical investigation, information was obtained concerning workers who had left the St. Lawrence area.

A total of 119 deaths occurred during 1933-61 among the approximately 2,000 men who had previously worked underground, on the surface, or in an official capacity for the mining companies. One death which occurred as a result of military action during World War II was excluded. These deaths were classified using the A-Intermediate List of the World Health Organization International Classification of Diseases (in use in Newfoundland since 1952) 
TUBERCULOSIS OF RESPIRATORY
SYSTEM AND SILICOSIS

\section{ALL MALIGNANT} NEOPLASMS

MAL. NEOPLASMS OF TRACHEA, BRONCHUS AND LUNG
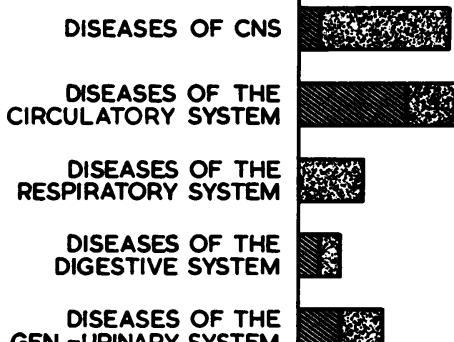

$1933-1951$

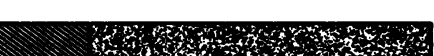

$1952-1961$ is

GEN. -URINARY SYST

ALL OTHERS

UNKNOWN
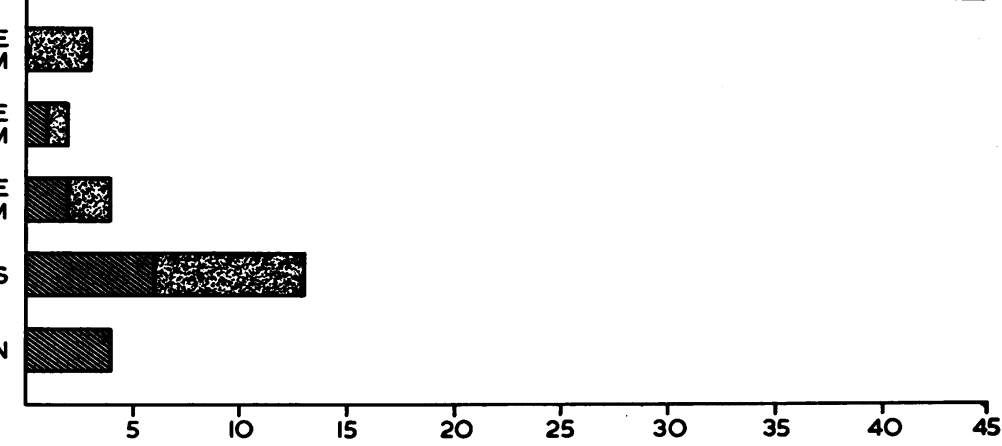

FIG. 2.-Classification of causes of death among men employees and ex-employees (surface and underground workers) of fluorspar mining companies, 1933-61.

TABLE 6

DEATHS, BY CAUSE* AND AGE GROUPS, AMONG MEN EMPLOYEES AND EX-EMPLOYEES (SURFACE AND UNDERGROUND WORKERS) OF FLUORSPAR MINING COMPANIES, 1933-61

\begin{tabular}{|c|c|c|c|c|c|c|c|c|c|c|c|c|}
\hline \multirow[b]{2}{*}{$\begin{array}{c}\text { Age } \\
\text { Group }\end{array}$} & \multirow{2}{*}{ 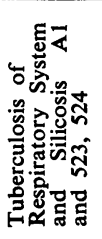 } & \multirow[b]{2}{*}{ 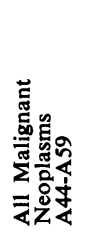 } & \multirow{2}{*}{ 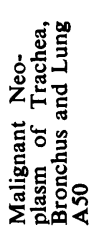 } & \multirow[b]{2}{*}{ 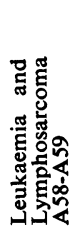 } & \multicolumn{6}{|c|}{ Diseases of } & \multirow[b]{2}{*}{$\begin{array}{l}5 \\
0 \\
5 \\
5 \\
5\end{array}$} & \multirow[b]{2}{*}{ 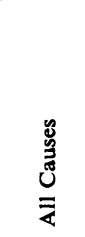 } \\
\hline & & & & & 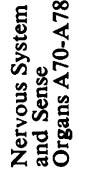 & 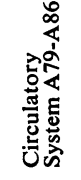 & 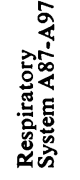 & 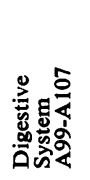 & 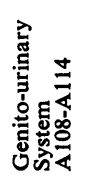 & 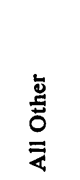 & & \\
\hline $15-24$ & & & & & & & & & & $(2,1)$ & $(1,0)$ & $(3,1)$ \\
\hline $25-34$ & $(6,0)$ & $\begin{array}{c}4 \\
(1,3)\end{array}$ & $(0,2)$ & & & $\begin{array}{c}1 \\
(0,1)\end{array}$ & $(0,1)$ & & & 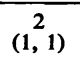 & $(1,0)$ & $\begin{array}{c}15 \\
(9,6)\end{array}$ \\
\hline $35-44$ & $\begin{array}{c}10 \\
(4,6)\end{array}$ & $(3,10)$ & $(1,8)$ & $\begin{array}{c}2 \\
(1,1)\end{array}$ & & $\begin{array}{c}3 \\
(1,2)\end{array}$ & & $(0,1)$ & $(1,0)$ & $(1,3)$ & & $\begin{array}{c}32 \\
(10,22)\end{array}$ \\
\hline $45-54$ & $(1,2)$ & $\begin{array}{c}11 \\
(1,10)\end{array}$ & $\begin{array}{c}8 \\
(0,8)\end{array}$ & & $\begin{array}{c}3 \\
(1,2)\end{array}$ & $(0,2)$ & & & $(1,1)$ & $\begin{array}{c}2 \\
(0,2)\end{array}$ & $(1,0)$ & $\begin{array}{c}24 \\
(5,19)\end{array}$ \\
\hline $55-64$ & $(0,3)$ & $(1,10)$ & $(0,7)$ & & $\begin{array}{c}1 \\
(0,1)\end{array}$ & $(2,5)$ & & $\begin{array}{c}1 \\
(1,0)\end{array}$ & & & & $\begin{array}{c}23 \\
(4,19)\end{array}$ \\
\hline $65-74$ & & $\begin{array}{c}2 \\
(1,1)\end{array}$ & & & $(0,3)$ & $\begin{array}{c}5 \\
(1,4)\end{array}$ & $(0,1)$ & & & & & $(2,9)$ \\
\hline 75 and over & & $\begin{array}{c}2 \\
(0,2) \\
\end{array}$ & & & & $(1,2)$ & $(0,1)$ & & $(0,1)$ & & & $(1,6)$ \\
\hline Unknown & & & & & & & & & & $(2,0)$ & $\begin{array}{c}1 \\
(1,0)\end{array}$ & $\begin{array}{c}3 \\
(3,0)\end{array}$ \\
\hline All ages & $\frac{22}{(11,11)}$ & $\begin{array}{c}43 \\
(7,36)\end{array}$ & $\begin{array}{r}26 * * \\
(1,25)\end{array}$ & $\begin{array}{r}2 * * \\
(1,1)\end{array}$ & $(1,6)$ & 21 (5,16) & $(0,3)$ & $(1,1)$ & $(2,2)$ & $(6,7)$ & $(4,0)$ & $(37,82)$ \\
\hline
\end{tabular}

First figure in brackets $=1933-51$; second figure $=1952-61$.

*1955 Revision A-Intermediate List, W.H.O. International Classification of Diseases.

**Included in total of 'all malignant neoplasms A-44-A-59'. 
and are summarized in the histogram (Fig. 2) by selected cause and in Table 6 by selected cause and age groups.

The medically certified cause of death was changed in two cases on the basis of the pathologists' reports on tissues obtained at necropsy. Both were changed to malignant neoplasm of the lung. In a number of cases no death certificate or death certificate diagnosis was available. Two such cases occurred during the period 1952-61. One of these was classified as leukaemia after the discovery of a pathologist's report, and the other as pneumonia in a young man on the basis of the Return of Death, a certificate issued by the local clergyman in the absence of a physician in order that burial might proceed. For the uncertified deaths that occurred before this time a probable cause of death was assigned, based on the diagnosis made during the deceased's previous hospital admission or on a Return of Death. In a few cases the diagnosis was obtained from parish records or as substantiated through further personal enquiries among relatives and friends of the deceased.

The principal causes of death in the group of 119 deaths are malignant neoplasms of all sites (43, including 26 deaths attributed to lung cancer), tuberculosis of the respiratory system (22, including three cases of pneumoconiosis), and diseases of the circulatory system (21). The subgroup of 26 deaths attributed to lung cancer is of particular interest.

Clinical Data.-An attempt was made to obtain all available clinical information on the deceased mining employees. All hospital and out-patient records in the hospital at St. Lawrence since its opening in 1954 were reviewed. Subsequently all hospitals in St. John's, to which patients were referred for special investigations or treatment, or to which they were admitted before the establishment of the local hospital at St. Lawrence, were visited, and a similar search was made. The Tuberculosis Dispensary in St. John's provided all available $x$-ray films and the Department of Pathology Services provided remaining tissues and other specimens for further study.

Clinical histories of the mining employees who died before 1952 were almost entirely unavailable, and, of those who died after 1952, some were incomplete. Similarly, radiographs relating to only 32 of the 119 deaths were obtained. This latter deficiency was due in part to the fact that fluorspar miners were radiographed only during the course of hospital admissions and as voluntary participants during tuberculosis surveys. In more recent years periodic radiographic examinations have been instituted.

Table 7 summarizes the basis for the diagnosis of lung cancer in 29 cases. These include the 26 deaths that occurred during 1933-61, one death that occurred during 1962, and two patients who were still alive in 1962.

These 29 cases were divided into the following groups:

Group 1.-Cases in which the diagnosis had been confirmed by microscopical examination of tissue obtained at necropsy or resection (16 cases).

Group 2.-Cases in which the microscopical proof available was based on examination of the sputum, bronchial aspirations, or pleural fluid, about which very little doubt remained after radiological and clinical investigation, e.g. bronchoscopy, bronchography, and thoracotomy (six cases).

Group 3.-Cases in which no microscopical supporting evidence was available. However, clinical and radiological evidence, including bronchoscopy in three cases and thoracotomy in two cases (in which inoperable masses were found), firmly supported the diagnosis of lung cancer (four cases).

Group 4.-Unconfirmed cases for which medical certificates are available, including one certificate stating that the diagnosis had been verified (case No. 24) but for which no clinical or other data could be obtained (three cases).

Radiographic examination of case 24 revealed probable malignant disease of the lungs but distinction between primary and secondary disease could not be made on radiological grounds alone.

Deaths due to respiratory tuberculosis and other malignant diseases were also reviewed in as much detail as possible. One case (14) was suggestive of pulmonary malignancy on the basis of bronchoscopic and radiological examination; two sputum examinations for malignant cells were reported as suspicious, but biopsy material revealed only 'healed' tuberculosis and pneumoconiosis.

The cause of death for case 33 was given as anaplastic carcinoma of the tonsil. Cases $\mathbf{3 1}$ and 32 were two mining employees who died of leukaemia. Two cases had proven histories of malignancy of the lip but died of causes other than malignant disease.

Further discussion in this section will be restricted to cases in groups 1,2 , and 3, which include 26 cases of lung cancer. The average age at death of the men with lung cancer was 46.8 years with a range of 33 to 56 years. The necropsy rate was five in 26 . Although it was not possible to determine the exact site of origin of the lung tumours, necropsy and clinical investigations indicated that the sites of bronchial involvement were grouped very approximately around the hilar regions, with only one tumour (case 7) clearly indicated as peripheral. 
TABLE 7

DEATHS FROM LUNG CANCER

\begin{tabular}{|c|c|c|c|c|c|c|}
\hline Case No. & Year of Death & Age & Probable Site & $\begin{array}{l}\text { Duration of } \\
\text { Underground } \\
\text { Exposure } \\
\text { (yr.) }\end{array}$ & $\begin{array}{c}\text { Induction } \\
\text { Period } \\
\text { (yr.) }\end{array}$ & $\begin{array}{c}\text { Lag-period } \\
\text { (yr.) }\end{array}$ \\
\hline $\begin{array}{r}\text { Group } 1 \\
2 \\
3 \\
5 \\
6 \\
7 \\
15 \\
18 \\
19 \\
22 \\
23 \\
25 \\
26 \\
27 \\
28 \\
29 \\
30\end{array}$ & $\begin{array}{l}1952 \\
1952 \\
1953 \\
1953 \\
1953 \\
1957 \\
1958 \\
1959 \\
1960 \\
1960 \\
1961 \\
\text { Living } \\
1961 \\
1961 \\
1962 \\
\text { Living }\end{array}$ & $\begin{array}{l}56 \\
56 \\
50 \\
37 \\
53 \\
40 \\
53 \\
43 \\
33 \\
34 \\
43 \\
41 \\
55 \\
45\end{array}$ & $\begin{array}{l}\text { Right anterior middle and posterior basic } \\
\text { Right main stem bronchus } \\
\text { Left hilar mass } \\
\text { Right main stem bronchus } \\
\text { Outer and middle zones right lower lobe } \\
\text { Right hilar region } \\
\text { Right main stem bronchus } \\
\text { Left main stem bronchus } \\
\text { Left main stem bronchus } \\
\text { Right hilar region } \\
\text { Right lower lobe bronchus } \\
\text { Left upper lobe bronchus } \\
\text { Left upper lobe bronchus } \\
\text { Left hilar region } \\
\text { Left lung } \\
\text { Lateral to upper pole right }\end{array}$ & $\begin{array}{r}13 \cdot 58 \\
13 \cdot 50 \\
10 \cdot 67 \\
11 \cdot 83 \\
14 \cdot 42 \\
8 \cdot 92 \\
15 \cdot 00 \\
12 \cdot 67 \\
9 \cdot 42 \\
12 \cdot 92 \\
21 \cdot 33 \\
17 \cdot 23 \\
17 \cdot 42 \\
15 \cdot 17 \\
5 \cdot 50\end{array}$ & $\begin{array}{c}17 \cdot 75 \\
19 \cdot 25 \\
16 \cdot 17 \\
12.92 \\
18.75 \\
21.92 \\
24.58 \\
18.42 \\
12.50 \\
17.75 \\
25 \cdot 43 \\
- \\
23.33 \\
- \\
20.50 \\
-\end{array}$ & $\begin{array}{l}0.42 \\
0.17 \\
0.25 \\
0.21 \\
0.33 \\
2.17 \\
5.58 \\
3.46 \\
2.17 \\
0.5 \\
1.29 \\
- \\
3.62 \\
2.17 \\
-\end{array}$ \\
\hline $\begin{array}{c}\text { Group } 3 \\
8 \\
11 \\
13 \\
20\end{array}$ & $\begin{array}{l}1954 \\
1955 \\
1956 \\
1959\end{array}$ & $\begin{array}{l}45 \\
52 \\
41 \\
49\end{array}$ & $\begin{array}{l}\text { Left peri-hilar region } \\
\text { Right hilar region } \\
\text { Right middle lobe bronchus } \\
\text { Right upper lobe bronchus }\end{array}$ & $\begin{array}{r}8 \cdot 92 \\
12 \cdot 92 \\
16 \cdot 75 \\
10 \cdot 42\end{array}$ & $\begin{array}{l}18 \cdot 42 \\
21 \cdot 5 \\
23 \cdot 0 \\
25 \cdot 0\end{array}$ & $\begin{array}{l}2 \cdot 17 \\
4 \cdot 38 \\
0 \cdot 33 \\
7 \cdot 83\end{array}$ \\
\hline $\begin{array}{r}\text { Group } 4 \\
1 \\
4 \\
24\end{array}$ & $\begin{array}{l}1949 \\
1953 \\
1960\end{array}$ & $\begin{array}{l}39 \\
62 \\
63\end{array}$ & $\begin{array}{l}\text { Information not available } \\
\text { Information not available } \\
\text { Information not available }\end{array}$ & $\begin{array}{c}8.42 \\
2.0 \\
15.83\end{array}$ & $\begin{array}{l}14.92 \\
20 \cdot 25 \\
26 \cdot 42\end{array}$ & $\begin{array}{c}2.04 \\
17 \cdot 25 \\
3.0\end{array}$ \\
\hline \begin{tabular}{c|} 
Group $5(\mathrm{sel}$ \\
14 \\
31 \\
32 \\
33
\end{tabular} & $\begin{array}{l}\text { ected other death } \\
1957 \\
1948 \\
1954 \\
1959\end{array}$ & $\begin{array}{l}46 \\
41 \\
40 \\
45\end{array}$ & $\begin{array}{l}\text { Left hilar mass } \\
\text { Myelogenous leukemia } \\
\text { Acute lymphatic leukemia } \\
\text { Anaplastic carcinoma of tonsil }\end{array}$ & $\begin{array}{c}15 \cdot 0 \\
8 \cdot 08 \\
1 \cdot 58 \\
3 \cdot 58\end{array}$ & $\begin{array}{l}21 \cdot 58 \\
22 \cdot 08\end{array}$ & $\begin{array}{c}1 \cdot 12 \\
3 \cdot 25 \\
0 \cdot 5 \\
13 \cdot 33\end{array}$ \\
\hline
\end{tabular}

The proportion of right to left sided tumours was 17 to nine (including case 29 for whom a bronchial site of origin has not yet been determined). The majority of the tumours in the right lung involved the middle and lower lobes.

The incidence of active and old or 'healed' tuberculous lesions could not be determined with accuracy from the clinical and radiological information. Tuberculosis was, however, suspected on the basis of radiological appearances in seven cases. In two of these seven cases, and in four others, cavities were suspected radiologically at one time or another. One cavitating tumour was demonstrated. Evidence of tuberculosis was found in the suspected case (14) mentioned earlier, and in another proven case of lung cancer a small area of calcification in the tumour suggested the presence of a long-standing inflammatory lesion with fibrosis.

The smoking histories for 20 cases were obtained from the clinical histories and a number of sources in the community. These revealed two non-smokers.

Available radiographs were reviewed separately by
Drs. A. R. Riddell and R. B. Sutherland, of the Silicosis Referee Board of Ontario. The radiological appearances were classified according to the system employed in the examination of miners in Ontario. The radiographs of 20 of the 26 cases in groups 1,2 , and 3 (Table 7) were reviewed. Radiological appearances that could be interpreted as being the result of prolonged exposure to a dusty working environment were present in four cases, suggestive in three, and absent in 13. A detailed investigation of the biopsy and necropsy material has not yet been completed.

Occupational Histories.-For the period 1937-61 occupational histories were obtained and underground exposures accurately calculated from halfmonthly payrolls. Payrolls for the period 1933-36 were destroyed by fire, but, with the help of census data, a company report, and mining company officials, the names and working histories of what is believed to be all who worked during those periods were obtained. Slightly exaggerated estimates of the 
duration of underground exposures for these individuals have been made. Intermittent surface, mill, and underground exposure, interspersed with periods of non-employment, was characteristic of almost all the deceased and other employees. Exposure to a dusty environment other than in the mines of St. Lawrence is considered to be insignificant.

Between 1933 and 1961, 69 deaths occurred among underground employees with more than 12 months' exposure out of 630 such employees in the total accumulated labour force. Except for one case (28), all the deaths from lung cancer occurred in this smaller underground population.

The average underground exposure for the deceased miners in groups 1,2 , and 3 (excluding case 28 who had no underground exposure) was 12.5 years, range 5.5 to 21.3 years. The longest underground exposure was that of case 25 , an official who spent between 50 and $70 \%$ of the usual eight-hour shift in an underground environment. To a lesser extent the duration of underground exposure of several other individuals (cases 3,13,19, and 24) was also affected by other surface employment. Case 28 spent nine months in the mill and 16.8 years in the compressor house on the surface.

Apart from one case that was not diagnosed until 10 years after a one-year residence in Newfoundland and hence was not reported in this study, the only known cases of lung cancer occurred among those who were from Newfoundland and who had lived in the St. Lawrence area since birth.

Using the occupational exposure data, an induction period was calculated. This is the time between the first underground exposure and death. Excluding cases 26 and 30, who were still living, and case 28, the average induction period came to $19 \cdot 1$ years with a range of 11.5 to 25 years. The interval between the last underground exposure and death, or the lag period, ranges between 0.17 years and 7.83 years, with an average of 1.8 years (excluding cases 26,28 , and 30).
Proportional Mortality Ratio.-An attempt was made to determine the differences between the number of deaths observed among mine employees and the number expected on the basis of the mortality experience for malignant neoplasm of the trachea, bronchus, and lung in the Province of Newfoundland as a whole. For this purpose age-specific proportional mortality ratios (P.M.R.) were calculated. The P.M.R. as used here refers to the ratio of 'all deaths due to lung cancer in Newfoundland less deaths due to lung cancer among St. Lawrence workers' to 'deaths due to all causes in Newfoundland less deaths due to all causes among the fluorspar workers'. From these P.M.R.s an expected mortality for lung cancer was derived for the deaths of 71 mine employees that occurred during 1952-60. The expected and actual deaths were compared, and ratios were determined for all ages and specific age groups (Table 8).

The observed incidence of lung cancer was 28.76 times the expected for this group of mining employee deaths. In the Newfoundland population, the maximum incidence occurs between the ages of 55 and 64 ; in the St. Lawrence population, a shift to a younger age group is indicated.

The method suggested by Doll (1958) and two other possible methods for estimating the relative risk gave values of $40.4,33.8$, and $25 \cdot 5$, respectively. Because of the relatively small number of deaths from lung cancer among the Newfoundland population, the comparatively small number of deaths due to other causes among the St. Lawrence miners, and an excess of lung cancer deaths among this group, the more conservative calculation of relative risk (28.76), as described above, has been preferred.

Mortality Experience of St. Lawrence and a Control Community.-To investigate the relationship between the incidence of lung cancer among fluorspar mining employees and the mortality experience of the entire community of St. Lawrence, population

TABLE 8

EXPECTED AND OBSERVED DEATHS DUE TO MALIGNANT NEOPLASM OF THE TRACHEA, BRONCHUS, AND LUNG (A50) AMONG MALE UNDERGROUND AND SURFACE MINE WORKERS AT ST. LAWRENCE, NEWFOUNDLAND, $1952-60$ INCLUSIVE*

\begin{tabular}{|c|c|c|c|c|c|c|c|c|}
\hline Number of Deaths & All Ages & $15-24$ & $25-34$ & $35-44$ & $45-54$ & $55-64$ & $65-74$ & $75+$ \\
\hline $\begin{array}{l}\text { a. Deaths from all causes, Newfoundland, less } \\
\text { deaths among St. Lawrence miners (1952-60) } \\
\text { b. Deaths due to malignant neoplasm of trachea, } \\
\text { bronchus, and lung, Newfoundland, less } \\
\text { deaths due to this cause among St. Lawrence } \\
\text { miners (1952-60) } \\
\text { c. Deaths from all causes, St. Lawrence miners } \\
\text { (1952-60) } \\
\text { Expected deaths, St. Lawrence }\left(\frac{\mathrm{b}}{\mathrm{a}} \times \mathrm{c}\right) \\
\text { Observed deaths, St. Lawrence }(1952-60) \\
\text { Ratio of observed deaths to expected deaths }\end{array}$ & $\begin{array}{c}157 \\
71 \\
0 \cdot 7303 \\
21 \\
28 \cdot 76\end{array}$ & $\begin{array}{l}1 \\
- \\
=\end{array}$ & $\begin{array}{c}4 \\
5 \\
0.0463 \\
2 \\
43 \cdot 20\end{array}$ & $\begin{array}{c}18 \\
19 \\
0.5681 \\
6 \\
10.56\end{array}$ & $\begin{array}{c}29 \\
17 \\
0 \cdot 5010 \\
8 \\
15.97\end{array}$ & $\begin{array}{c}1,545 \\
\\
61 \\
16 \\
0.6317 \\
5 \\
7.92\end{array}$ & $\begin{array}{c}31 \\
9 \\
0.0991 \\
=\end{array}$ & $\begin{array}{c}3,570 \\
13 \\
5 \\
0.9182 \\
=\end{array}$ \\
\hline
\end{tabular}

*Cases in categories 1 to 3 only. 
and mortality data for $1952-59$ inclusive were collected. To examine the differences between the population characteristics and the cause of death data of St. Lawrence and those of other parts of the Province, data were also collected for Newfoundland, Burin Peninsula, and the town of Grand Bank.

Grand Bank lies on the western coastline of the Burin Peninsula, approximately 30 miles by air north-west of St. Lawrence. These two communities have many characteristics in common and lie in the same geographical region, but the inhabitants of Grand Bank have at no time taken part in the fluorspar mining industry at St. Lawrence. It is for these reasons that Grand Bank was selected as a control community for all phases of the study.

Comparisons were made between the data for St. Lawrence and Grand Bank, between St. Lawrence and 'Newfoundland less St. Lawrence and Grand Bank', and between Grand Bank and 'Newfoundland less St. Lawrence and Grand Bank'. In these comparisons reference was made to population characteristics by sex and age groups (Table 9), eight-year death rates by sex and age groups, and deaths by age groups for certain causes (Table 10). Broad age groups were used throughout this analysis because of the small numbers occurring in the mortality data for St. Lawrence and Grand Bank.

Although the total population of St. Lawrence $(2,078)$ is comparable in size to that of Grand Bank $(2,430)$, there were differences in the distribution of the population in certain age groups. Of particular interest is the smaller proportion of males in the age group 20-64 years in St. Lawrence as compared with both Grand Bank and Newfoundland as a whole. On the other hand, the male death rate for St. Lawrence in this age group was significantly higher than that for either Grand Bank or Newfoundland (119.0 per 1,000 population as compared with 50.7 and 36.6 per thousand, respectively). The death rates for St. Lawrence females in the age group 'all ages' are significantly lower than those for Newfoundland, which, in turn, are lower than those for Grand Bank.

The selected 'cause of death' groups, by age group for the male populations of St. Lawrence and Grand Bank, are given in Table 10. Ninety-six male deaths, including 58 mine employee deaths, among both surface and underground workers, occurred in St. Lawrence during the period 1952-59. Grand Bank had a total of 98 male deaths in the same period.

Major differences occurred primarily in the two cause groups, 'tuberculosis, including silicosis' (A1 and 523) and 'malignant neoplasm of all sites' (A44-A59). However, when the sub-group 'malignant neoplasm of trachea, bronchus, and lung' (A50) was excluded from 'malignant neoplasm of all sites', the differences in this latter group became negligible. In the sub-group 'malignant neoplasms of trachea, bronchus, and lung', the number of male deaths observed in St. Lawrence in the age group 20-64 years was very much higher than expected on the basis of comparisons with Grand Bank and with Newfoundland.

There were no important cause group differences between the female population of St. Lawrence and Grand Bank or of St. Lawrence and Newfoundland. Some differences occurred when the data for females of Grand Bank were compared with those of Newfoundland, but these did not involve malignant neoplasms of the trachea, bronchus or lung.

These comparisons revealed no differences of importance to the present study other than those which can be directly related to the male population in St. Lawrence. Further analysis of the data showed that, in the male age group 20-64, tuberculosis of the respiratory system, including pneumoconiosis,

TABLE 9

POPULATION, BY SEX AND AGE GROUP, OF ST. LAWRENCE, GRAND BANK, AND NEWFOUNDLAND (According to the 1956 census data)

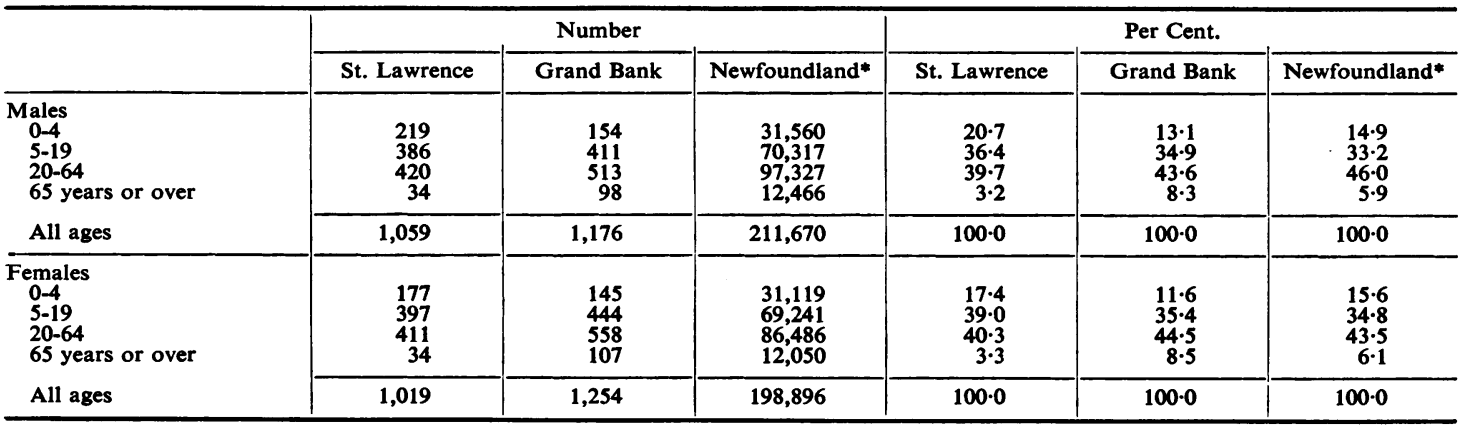

*Newfoundland less St. Lawrence and Grand Bank. 
TABLE 10

MALE DEATHS, 1952-59, BY AGE GROUP FOR CERTAIN CAUSES IN (a) ST. LAWRENCE AND (b) GRAND BANK

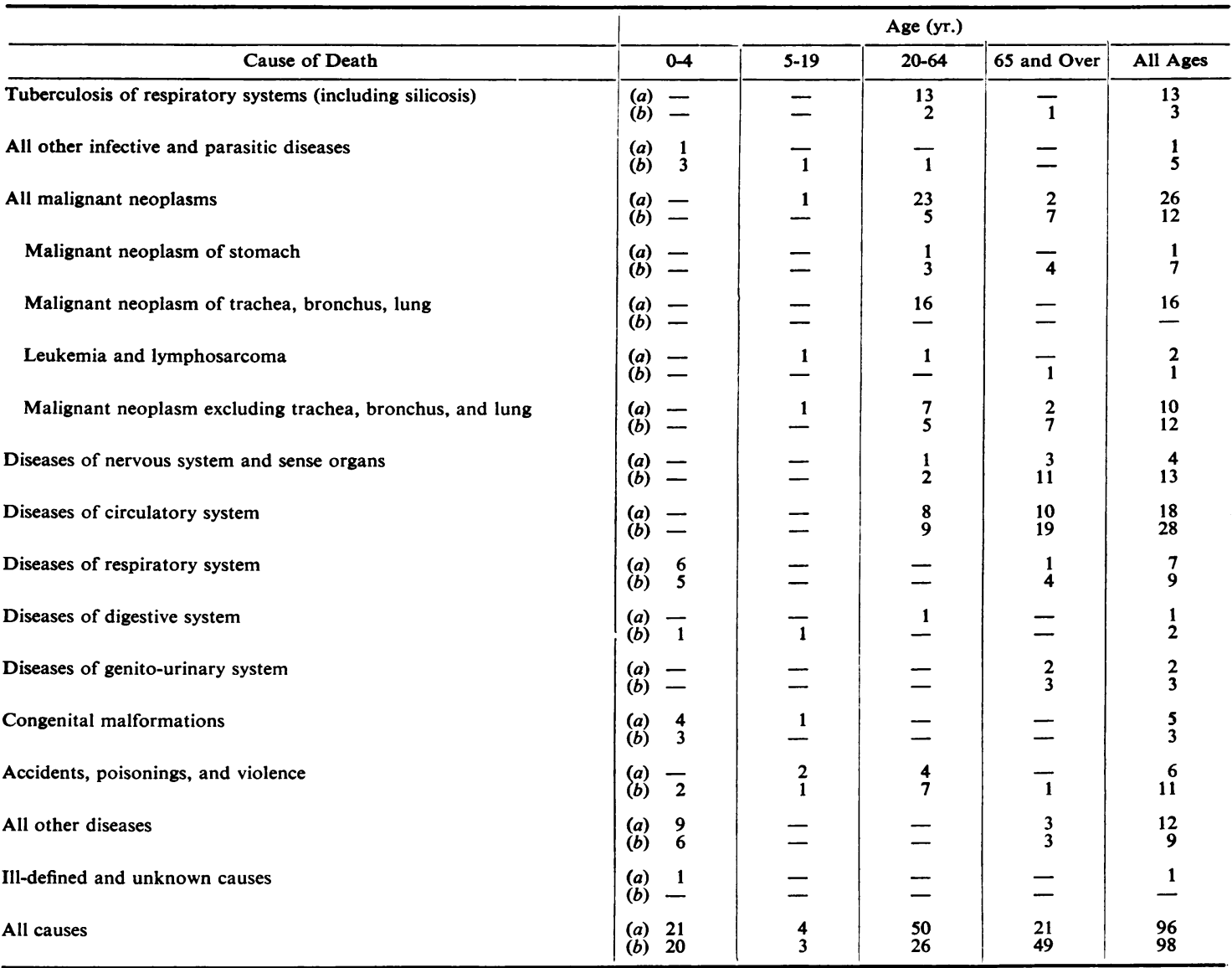

affected primarily mining employees, whereas lung cancer affected only mining employees.

\section{Discussion}

Accuracy of Diagnosis.-The comparatively high tuberculosis mortality among St. Lawrence miners (the radiological and other findings suggesting tuberculous infection in men eventually dying of lung cancer) together with a low necropsy rate for the series suggest the possibility of an appreciable underdiagnosis factor. However, the influence of such a factor on the apparent incidence of lung cancer in St. Lawrence during 1952-61 has been considerably offset by medical awareness of the problem, prompt referral and investigation of all suspected cases in a large hospital centre, the comparatively short average underground exposure of men with respira- tory tuberculosis (6.87 years for seven miners), and the certain expectation of a number of cases of tuberculosis among individuals exposed to the complicating effects of prolonged (and for long uncontrolled) underground dust exposure. As a consequence of the exclusion of group 4 (Table 7) the probability of overdiagnosis is slight.

The more frequent reliance on diagnoses obtained from Returns of Death and the high tuberculosis mortality in the general population of Newfoundland (457 per 100,000 population in $1933 ; 197$ per 100,000 in 1951, all ages and both sexes) increases the probability of underdiagnosis of lung cancer during 1933-51. During this period only one case was diagnosed but was placed in group 4 because clinical evidence was lacking.

The extent of over- and under-diagnosis in the Province of Newfoundland as a whole is subject to 
similar influences. Possible differences between the accuracy of diagnosis in St. Lawrence as compared with other parts of Newfoundland probably diminished with the provision of improved medical care facilities to all parts of the Province. This opinion is supported by the findings of the Cancer Incidence Committee, a committee organized in 1956 to study the incidence of cancer in Newfoundland in cooperation with the National Cancer Institute of Canada. It was the opinion of the committee that very few cases of cancer were missed during the period of its study (1956-61) (personal communication from Dr. A. J. Phillips, National Cancer Institute of Canada).

The mortality rate (Canadian Vital Statistics Reports) for lung cancer among males for the same period (1956-61) was $0 \cdot 11$ per 1,000 population for Newfoundland as compared with 0.24 per 1,000 population for the other provinces of Canada (based on annual population estimates) and 2.33 per 1,000 population for St. Lawrence (based on groups 1 to 3, Table 7, and the 1956 census).

Earlier Age at Death of St. Lawrence Cases.-In addition to an increased incidence of lung cancer at St. Lawrence, there has also been a shift in the average age at death to involve younger age groups as compared with the Newfoundland population. An earlier age at death may be due to a more limited survival time from the onset of the disorder; to a

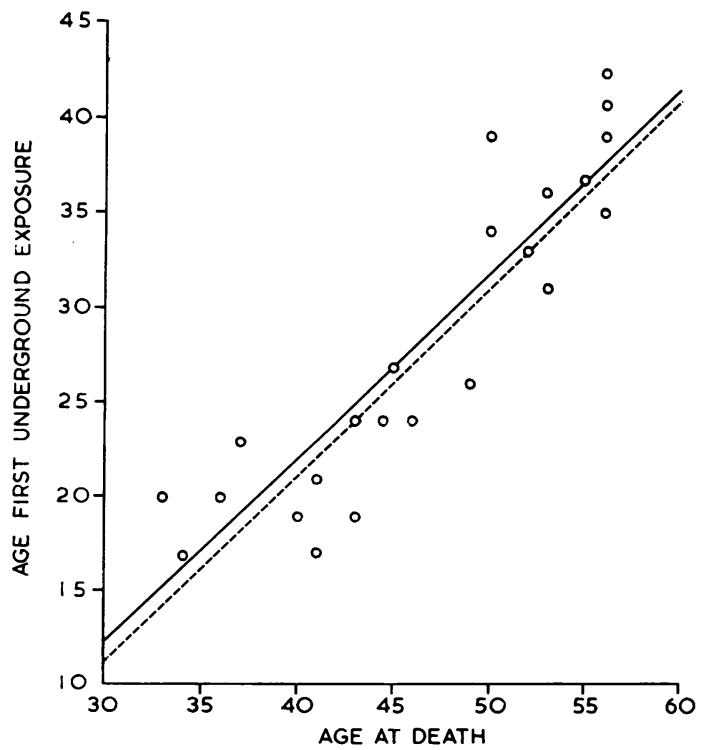

Fig. 3.-Age at entry into risk and age at death (excluding cases 1,4 , $24,26,28,30)$. Solid line: line of regression of $Y$ on $X(r=0.91)$ broken line: theoretical age at death for an average induction time of $19 \cdot 1$ years. selectively greater susceptibility to the disease in younger men; to a relationship between the age at first exposure to risk and the age at onset; or some combination of these factors (Case, Hosker, McDonald, and Pearson, 1954). We do not believe that any significant differences exist with respect to survival time between our series and others. The effect of age on susceptibility will be explored more fully in the detailed occupational mortality study. For all practical purposes, the data suggest that the age at death is entirely dependent upon the age at entry into risk (Fig. 3). Whether this is due to an association between dose, in terms of accumulated duration of underground exposure, and survival time (with the data in their present form no such direct association could be demonstrated), to a simple threshold effect or a combination of factors is uncertain.

Inhalation Hazards.-An inhalation hazard is suggested by the distinct hilar distribution of the tumours and the greater involvement of the right lower lobe, which normally receives the greater portion of the tidal volume (Altman, 1958).

Nickel, chromium, beryllium, yttrium, samarium147 , and uranium are very minor constituents of the rock and ore. In the concentrations found, their role as site potentiators or producers of cancer is uncertain. So, too, is the chemical action of calcium fluoride. Furthermore, no importance can at present be attached to the presence of silica or pneumoconiosis other than that the latent period for the development of pneumoconiosis appears to be longer than that for the development of lung cancer.

Exposure to radon and its daughters appears to be the most important single hazard.

Source of Radon.--Uranium and radium must be present in the area to account for the radon, but so far the only evidence of their presence has been the detection, in only one out of 16 representative rock samples, of an amount of radioactivity equivalent to less than $0.005 \% \mathrm{U}_{3} \mathrm{O}_{8}$. This suggests that most of the radon is not being emanated directly into the mine air from radium in place in the exposed rock walls but is being carried in by some other means. This appears to be the mine water, which has always been plentiful in all mines. Calculations involving the total open space in mine No. 5, the total estimated number of air changes per day, and the estimated daily flow of water through the mine (as these factors existed at the time of our study) indicate that if each litre of water gave off to the air approximately $6,000 \mathrm{pc}$ of radon, the concentration of radon in the air of the whole mine would be maintained at 100 pc per litre. Samples of water taken at the main 
sump on the bottom level and at a dam on the second level contained 4,240 and 12,850 pc of radon per litre, respectively. By the time the water had reached the sump and the dam, much of it had travelled many hundreds of feet in open places in the mine and had probably released much of its radon to the air. It thus seems reasonable to conclude that the immediate source of the radon in the mine air is the mine water.

Average Concentration of Radon Daughters.-The older mines in the area had been closed and allowed to flood before we began our measurement of radiation levels. Until these mines are de-watered and reopened and radiation concentrations are measured, there is no basis on which to decide whether their concentrations of radon and radon daughters were higher or lower than those in the mines we did measure. Lacking evidence to the contrary, we are assuming that their levels of radioactivity were of the same order of magnitude as those we measured. On the basis of our present knowledge, the fact that no radioactive ore bodies have been found, and the average concentrations for mines Nos. 4 and 5 calculated in the 'Data' section of this report, it is suggested that the St. Lawrence miners were probably exposed to an average radon daughter concentration in the range $2.5-10 \times \operatorname{SWL}\left(3.25-13 \times 10^{5} \mathrm{Mev}\right.$ per litre).
Comparison of Data with those from Other Areas.-A comparison of the more important findings relating to St. Lawrence, Jachymov and Schneeberg, and the uranium mines of South Africa and the United States of America is given in Table 11.

The incidence of lung cancer at St. Lawrence, as a percentage of miner deaths, ranges between $33.3 \%$ (23 of 69 underground miner deaths 1933-61) and $45 \cdot 1 \%$ (23 of 51 underground miner deaths 1952-61).

From a study of data that had been published previously by others, Evans and Goodman (1940) calculated the average radon concentration in the mines of Jachymov and Schneeberg to be 2,900 pc per litre. In the review by Lorenz (1944) of available data for these areas, reference was made to 781 deaths (excluding necropsy series) which occurred among miners between 1875 and 1939. Of these, 336 or $43 \%$ were due to lung cancer. However, only 116 of these deaths occurred during 1921-39, according to reports by Rostoski and others (1926) quoted by Lorenz (1944), Hueck (1939) quoted by Lorenz (1944), and Peller (1939). Of these, 60 or $51.7 \%$ were due to lung cancer.

The average duration of underground or radium factory exposure of nine cases from Jachymov, as described by Pirchan and Šikl (1932), was 17 years (range 13-23); the time between the beginning of work in the mines and death from cancer was from 15 to 43 years (average 25 years); the age at death

TABLE 11

COMPARISON OF ST. LAWRENCE, JACHYMOV AND SCHNEEBERG, COLORADO PLATEAU, AND SOUTH AFRICA DATA

\begin{tabular}{|c|c|c|c|c|c|c|}
\hline & \multirow{2}{*}{\multicolumn{2}{|c|}{$\begin{array}{c}\text { Fluorspar Mines } \\
\text { St. Lawrence }\end{array}$}} & \multicolumn{4}{|c|}{ Uranium Mines } \\
\hline & & & \multicolumn{2}{|c|}{ Jachymov and Schneeberg } & \multirow{2}{*}{$\begin{array}{l}\text { Colorado } \\
\text { Plateau } \\
\text { Working } \\
\text { Mines }\end{array}$} & \multirow{2}{*}{$\begin{array}{l}\text { South Africa } \\
\text { Working } \\
\text { Mines }\end{array}$} \\
\hline & $\begin{array}{c}\text { Dead-end } \\
\text { Areas }\end{array}$ & $\begin{array}{c}\text { Ventilated } \\
\text { Areas }\end{array}$ & $\begin{array}{l}\text { Abandoned } \\
\text { Mine }\end{array}$ & $\begin{array}{l}\text { Working } \\
\text { Mine }\end{array}$ & & \\
\hline $\begin{array}{l}\text { Radon (pc per litre) } \\
\text { Average } \\
\text { Range } \\
\text { Radon daughters (multiples of } 1.3 \times 10^{5} \\
\text { Mev per litre) } \\
\text { Average } \\
\text { Range }\end{array}$ & $270-25,000^{*}$ & $\begin{array}{l}<5-1,510 \\
2 \cdot 5-10^{* *} \\
0-12\end{array}$ & $?-54,000^{1}$ & $\begin{array}{r}2,900^{2} \\
360-18,000^{3} \\
7-7,000^{1}\end{array}$ & $70-59,000^{7}$ & $25-500^{\circ}$ \\
\hline $\begin{array}{l}\text { Gamma radiation (mr./hr) } \\
\text { Incidence of lung cancer as \% of miner } \\
\text { deaths } \\
\text { Duration of underground exposure (years) } \\
\text { Average and range } \\
\text { Induction period (years) } \\
\text { Average and range } \\
\text { Age at death (years) } \\
\text { Average and range }\end{array}$ & $\begin{array}{l}0 \cdot 03-0 \\
33(193 \\
45(195 \\
12 \cdot 5(5 \\
19 \cdot 1(1 \\
46 \cdot 8(3\end{array}$ & $\begin{array}{l}0 \\
-61) \\
-61) \\
-21 \cdot 3) \\
5-25 \cdot 0) \\
-56)\end{array}$ & $\begin{array}{l}43(18 \\
52(19 \\
17(13 \\
25(15 \\
50(40 \\
55(37\end{array}$ & $\begin{array}{l}-1939)^{4} \\
-39)^{4} \\
3)^{5} \\
7^{5}\end{array}$ & $\begin{array}{l}11 \cdot 4^{8} \\
7,8,9,10,12\end{array}$ & $\begin{array}{l}3 \cdot 5^{9} \\
17 \cdot 3(3-30)^{10} \\
58 \cdot 2(45-73)^{9}\end{array}$ \\
\hline $\begin{array}{l}\text { *Estimated, on basis of highest radon daug } \\
\text { **Estimated. } \\
\text { 1Rajewsky (1939), quoted by Lorenz (19. } \\
\text { between } 1936 \text { and } 1939 . \\
\text { 'Evans and Goodman (1940). } \\
\text { 'Ludewig and Lorenser (1924) quoted by } \\
\text { 'Affer Lorenz (1944). } \\
\text { 5Nine cases-Pirchan and Sikl (1932). }\end{array}$ & $\begin{array}{l}\text { ter concentrati } \\
\text { 4); measureme } \\
\text { Lorenz (1944). }\end{array}$ & $\begin{array}{l}\text { n found. } \\
\text { ts made }\end{array}$ & $\begin{array}{l}\text { 4hirteen cases- } \\
\text { Holaday } \text { et al. } \\
\text { Miners with th } \\
\text { s-Archer } \text { et a } \\
\text { Oosthuizen } \text { et } \\
\text { Based on } 14 \text { of }\end{array}$ & $\begin{array}{l}\text { ostoski and } \\
\text { 57); data coll } \\
\text { or more yei } \\
\text { 1962). } \\
\text { (1958). } \\
\text { cases reporte }\end{array}$ & $\begin{array}{l}\text { ers (1926) quc } \\
\text { ed in } 1952 \text {. } \\
\text { underground } \\
\text { y Oosthuizen } e\end{array}$ & $\begin{array}{l}\text { experience-five } \\
\text { al. (1958). }\end{array}$ \\
\hline
\end{tabular}


ranged between 40 and 67 years (average 50 years). The average age at death of 13 cases from Schneeberg described by Rostoski and others (after Lorenz, 1944) was 55 years (range 37-69 years).

In 1952 the range of radon concentrations found in uranium mines in the United States of America was $70-59,000 \mathrm{pc}$ per litre (Holaday et al., 1957). These figures are given to indicate the range that is known to have occurred; they do not necessarily reflect present-day working conditions. Large-scale mining of uranium ore in the United States started during World War II, but the number of miners involved at first was only a few hundred. Lung cancer accounted for five of 44 deaths, or $11.4 \%$, among 907 white underground miners aged 20 years and over and with three or more years of underground uranium mining experience as of 1957 (Archer, Magnuson, Holaday, and Lawrence, 1962). The fact that the uranium mining industry in the United States is still a comparatively recent one, and the difficulties associated with observing and interpreting findings concerning a highly mobile group of miners, emphasize the opinion of Archer and others that it is still too early to define with precision the health status of uranium miners in the United States.

According to Oosthuizen, Pyne-Mercier, Fichardt, and Savage (1958), radon concentrations in South African gold and uranium mines were of the order of 25-50 pc per litre of air in areas where the uranium content of the ore is unpayable with occasional values of $200-300 \mathrm{pc}$ per litre. In areas where the ore is payable, the radon concentrations were of the order of $100-500 \mathrm{pc}$ per litre of air. The large amount of ventilation required in their mines might be thought necessarily to lead to low radon and daughter concentrations; however, as Oosthuizen points out, this supposition may not be correct, for the operation of other factors, such as long intake airways, series ventilation, and low air-change rates may all have the net effect of allowing considerable radon and daughter concentrations in many working areas. High ventilation standards have, however, been maintained for a considerable period of the more than 60 years of mining operations in these South African mines. Uranium oxide associated with gold occurs in the conglomerates at various horizons of the Witwatersrand and other systems. Although uranium production did not start until the early 1950's, it can be assumed that the potential hazards associated with the presence of uranium ore existed since virtually the beginning of the goldmining industry in South Africa.

The incidence of lung cancer, as reported by Oosthuizen et al. (1958) on the basis of a series of necropsies on miners, was $3.5 \%$ or 23 cases among 650 necropsies, as compared with $5.4 \%$ of a series of 500 consecutive non-miner, male necropsies at the same hospital. There appeared to be no significant differences between the two series as far as average age at death and maximal age at death were concerned. No increased incidence with increased length of service or increased incidence with increased degree of silicosis could be demonstrated. While the defects inherent in necropsy series and discrimination against the elderly silicotic were admitted and discussed, the authors concluded that radioactivity of the air in the South African mines did not represent a serious health hazard.

This opinion is to some extent supported by many years of necropsy experience in that country. On the other hand, the hazard associated with the higher radon concentrations found in the payable ore areas of the gold mines cannot as yet be fully evaluated because of the comparatively recent emphasis on uranium mining in South Africa.

In Colorado, Jacoe (1953) measured radon concentrations in a number of non-uranium mines. Samples were usually collected at the working face. The highest values found in three of the $\mathbf{3 0}$ metal mines studied were 2,100 and 1,200 pc per litre (ventilation stated to be poor in both cases) and $575 \mathrm{pc}$ per litre (mine said to contain small, uneconomic quantities of pitchblende). Concentrations in the other 27 metal mines ranged from 10 to $340 \mathrm{pc}$ per litre. In 12 clay and coal mines, concentrations ranged from 0 to $540 \mathrm{pc}$ per litre. In New York State, Harris (1954) investigated 14 underground workings, including a cavern, an abandoned mine, and iron, talc, gypsum, and rock-salt operating mines. Sampling was done primarily in dead-end drifts where the ventilation was said to be effectively zero. The highest radon concentration found was $110 \mathrm{pc}$ per litre in the cavern; in the mines, values ranged from $0 \cdot 1$ to $40 \mathrm{pc}$ per litre. No clinical information is at present available for these areas.

The data in Table 11 suggest that there may be some association between the average levels of radioactivity in the air and the incidence of lung cancer. Assuming the validity of these comparisons and using the duration of exposure, induction period, and age at death as a measure of the severity of 'risk', the differences noted between the St. Lawrence data and those for Jachymov and Schneeberg become of interest. These differences may be due in part to the more accurate computation of the duration of exposure that was used for the St. Lawrence miners. They may be altered by consideration of the effects of a younger age at entry into risk, consideration of inaccuracies inherent in the use of the incidence of lung cancer as a percentage of total deaths, and by a more accurate estimate of the average concentration of radioactivity to which the 
St. Lawrence miners were exposed. This latter factor will require more measurements in stopes under conditions of ventilation similar to those that existed before mechanical ventilation was installed and, if possible, measurements in mines that are now closed. Such factors are being investigated.

\section{Conclusion}

The data presented support the hypothesis that an occupational factor is involved in the aetiology of lung cancer among the fluorspar miners of St. Lawrence, at least as a precipitating or site-potentiating factor. The most important single or contributing factor known is exposure to relatively high concentrations of radon and its daughters in the mine air.

The list of all the people who have contributed to this study is lengthy. We are greatly indebted to each of them. In particular we wish to mention Dr. L. Miller, Deputy Minister of the Newfoundland Department of Health and Dr. C. J. Walsh, Physician-in-charge of the St. Lawrence area at the time of our study; Dr. F. de N. Brent, Director of Medical Services, Aluminum Company of Canada, Ltd.; Mr. D. A. Poynter, Mine Manager, St. Lawrence Corporation of Newfoundland, Ltd.; Mr. R. Wiseman, General Manager, Newfoundland Fluorspar Ltd.; Drs. A. R. Riddell and R. B. Sutherland of the Silicosis Referee Board of Ontario; Mr. H. G. Page, Chief, Vital Statistics Section, Dominion Bureau of Statistics; Mr. Charles H. Tobin, Registrar, Vital Statistics Division, Newfoundland Department of Health; Dr. K. W. Downes and the staff of the Extraction Division, Mines Branch, Department of Mines and Technical Surveys; Dr. G. H. Josie, Directorate of Health Services, Miss Barbara Stuart, Research and Statistics Division, Dr. P. M. Bird and the staff of the Radiation Protection Division, Dr. T. H. Patterson and the staff of the Occupational Health Division, Department of National Health and Welfare. We also thank Dr. C. G. Stewart, Director, Medical Division, and Dr. S. D. Simpson, Branch Head, Medical Research Branch, Atomic Energy of Canada
Ltd. for their continued advice and assistance throughout the course of this study.

\section{REFERENCES}

Adamson, J. D., Jollife, N., Kruse, H. D., Lowry, G. H., Moore, P. E., Platt, B. S., Sebrell, W. H., Tice, J. W., Tisdall, F. F., Wilder, R. M., and Zemechnik, P. C. (1945). Medical Survey of Nutrition in Newfoundland. Murray, Toronto, Canada.

Altman, P. L. (1958). Handbook of Respiration, ed. D. S. Dittmar and R. M. Grebe, p. 45. Saunders, Philadelphia and London.

Archer, V. E., Magnuson, H. J., Holaday, D. A., and Lawrence, P. A. (1962). Hazards to health in uranium mining and milling. J. occup. Med., 4, 55 .

Carr, G. F. (1958). The Industrial Minerals of Newfoundland. Dept. of Mines and Technical Surveys, Ottawa, Mines Branch, Publication No. 855.

Case, R. A. M., Hosker, M. E., McDonald, D. B., and Pearson, J. T. (1954). Tumours of the urinary bladder in workmen engaged in the manufacture and use of certain dyestuff intermediates in the British chemical industry. Part I. The role of aniline, benzidrine, alpha-naphthylamine and beta-naphthylamine.

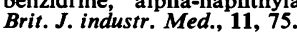

Doll, R. (1958). Cancer of the lung and nose in nickel workers. Ibid. 15, 217.

Evans, R. D., and Goodman, C. (1940). Determination of the thoron content of air and its bearing on lung cancer hazards in industry. J. industr. Hyg., 22, 89.

Garland, T. O., and Hart, P. D. (1946). 1945. Tuberculosis in Newfoundland. Trade Printers and Publishers Ltd., London.

Harris, S. J. (1954). Radon levels found in mines of New York State. Arch. industr. Hyg., 10, 54.

Holaday, D. A., Rushing, D. E., Coleman, R. D., Woolrich, P. F., Kusnetz, H. L., and Bale, W. F. (1957). Control of Radon and Daughters in Uranium Mines and Calculations on Biologic Daughters in. Pranium Mects. U.S. Public Health Service Publication No. 494.
Effen

I.C.R.P. (1959). Recommendations of the International Commission on Radiological Protection. I.C.R.P. Publication No. 2. on Radiological Protection. I.C.R.P. Publication No. 2. Report of Committee II on Permissible Dose for
Radiation. Pergamon Press, New York and London.

Jacoe, P. W. (1953). Occurrence, of radon in non-uranium mines in Colorado. Arch. industr. Hyg., 8, 118.

Kusnetz, H. L. (1956). Radon daughters in mine atmospheres: a field method for determining concentrations. Amer. industr. Hyg. Ass. Quart., 17, 85.

Lorenz, E. (1944). Radioactivity and lung cancer: a critical review of lung cancer in the miners of Schneeberg and Joachimstal. J. nat. Cancer Inst., $5,1$.

Oosthuizen, S. F., Pyne-Mercier, W. G., Fichardt, T., and Savage, D. (1958). In Proceedings of 2nd U.N. Int. Conf. on Peaceful

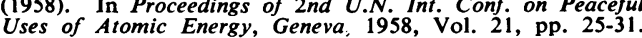
Uses of Atomic Energy,
United Nations, Geneva.

Peller, S. (1939). Lung cancer among the mine workers in Joachimstal. Hum. Biol. . 11, 130.

Pirchan, A., and Šikl, H. (1932). Cancer of the lung in the miners of Jachymov (Joachimstal). Amer. J. Cancer, 16, 681.

Simpson, S. D., Stewart, C. G., Yourt, G. R., and Bloy, H. (1958). In Proceedings of 2nd U.N. Int. Conf. on Peaceful Uses of Atomic Energy, Vol. 23, pp. 195-201. United Nations, Geneva.

Snelgrove, A. K., and Baird, D. M. (1953). Mines and Mineral Resources of Newfoundland. Information Circular No. 4. Resources of Newfoundland. Information Circular No. 4. Geological Survey, Mines Branch, Depart

Van Alstine, R. E. (1948). Geology and Mineral Deposits of the St. Lawrence Area, Burin Peninsula, Newfoundland. Bulletin No. 23 of Newfoundland Geological Survey. 